\title{
RELIGION AND LOCAL POLITICS Exploring the Subcultures and the Political Participation of East Java NU Elites in the Post-New Order Era
}

\author{
Abdul Chalik \\ IAIN Sunan Ampel, Surabaya - Indonesia
}

\begin{abstract}
The history of the involvement of NU in politics cannot be separated from the elites of this organization in East Java. The variety of cultures that flourishes in the province strongly influences the nature and characteristics of the NU elites. This paper is an attempt to deal with the relationship between those subcultures and political participation. It focuses only on five subcultures, Mataraman, coastal areas, Arek, Madurese, and Pendalungan. The NU kiais are perceived by their followers to have played double roles as religious leaders (dealing with spiritual aspects) and community leaders (relating to sociopolitical aspects). Locality and its growing culture become a key factor. Locality makes a contribution to the growth of understanding about politics. Mataraman NU elites always keep their relationship with formal religious issues, and there is a tendency among them to separate religion from politics. In contrast, Madura, Pendalungan, Pesisiran (north coast), and Arek areas tend to combine religion and politics.
\end{abstract}

Keywords: East Java NU, Hybridization, Amalgamation, political participation, Aswaja.

\section{Introduction}

Nahdlatul Ulama' (NU, The Awakening of Muslim Scholars), is the largest religious organization in Indonesia. There are no definite statistics on the number of NU members, but based on a survey conducted in 1994, the number of NU members is estimated to exceed 
35 million. $^{1}$ Another survey conducted by the Lembaga Survei Indonesia (LSI, Indonesian Survey Institute) in 2004, indicated that the number of NU members may be as high as 60 million. ${ }^{2}$

NU was established in Surabaya in 1926 by several prominent ulama $\ngtr$ Muslim scholars, Indonesian "kyai") and traders. It was born in an atmosphere of adversity, mentally and economically, either because of Dutch colonialism or the confines of tradition. Downturns experienced by the Indonesian people inspired educated figures to fight for their dignity through education and organization.

The history of the involvement of NU in politics cannot be separated from the elites of this organization in East Java, the province in Indonesia with the largest number of Islamic boarding schools. Consequently, the NU Party, and parties having a close relationship with NU, received a considerable number of votes in the $1955,{ }^{3} 1971$, 1999 and 2004 general elections in East Java.

East Java is the most populous province in Indonesia. ${ }^{4}$ In terms of culture, it can be divided into several subcultures. According to Ayu Sutarto, ${ }^{5}$ viewed from its cultural heritage, there are at least ten subcultures that flourish in East Java. These Subcultures include Mataraman, Ponoragan, Samin, Tengger, coastal areas, Arek, Madurese, Pendalungan, and Osing. All of these subcultures have different language characteristics but some of them have a common history.

The variety of cultures that flourishes in East Java strongly influences the nature and characteristics of the NU elites since they

1 Greg Fealy and Greg Barton, Tradisionalisme Radikal; Persinggungan Nabdlatul Ulama' dan Negara, transl. by Ahmad Suaedy, et al (Yogyakarta: LKiS, 1997), p. xiii.

2 Masyhudi Muchtar and Mohammad Subhan, Profil NU Jawa Timur (Surabaya: LTNU, 2007), p. 12.

${ }^{3}$ For example, the general election 1955, NU in East Java gained 3.206. 392 from total votes of 6.989.333. Greg Fealy, Ijtibad Politik Ulama; Sejarah NU 1952-1967, transl. by Farid Wajidi and M.A. Bakhtiar (Yogyakarta: LKiS, 2007), p. 221.

4 The population of East Java is $35,148,579$ inhabitants, with male population: $17,249,198$, female; $17,899,381$, while the total area is $157,130,15 \mathrm{~km} 2$. In terms of religion, Islam, 96, 3\% Christian, 1.6\%; Catholic, 1\%, Buddhist, and Hindu 0.4\%, 0, 6\%. See wnw.depdagri.go.id. (Accessed on 22 February 2009). From the government side, East Java is divided into 29 districts and 9 Cities, Districts 657 and 8484 villages. See wnw. Jatimprov.go.id. (Accessed on 22 Pebruari 2009).

5 See Ayu Sutarto, Setya Yuwana Sudikan (ed.), Pemetaan Kebudayaan Propinsi Jawa Timur; Sebuah Upaya Pencarian Nilai-nilai Positif (Jember: Kompyawisda, 2008), p. iv. 
reside insuch a heterogeneous environment. According to Gabriel A. Almond and Sydney Verba, a culture which develops in one area is likely to have links with its local politics, democracy or even political figures. ${ }^{6}$ Almond and Verba's analysis refers to the so-called political culture, namely the psychological orientation toward social objects, which constitutes a political system. A person's positive or negative attitude towards the political system depends on the motive of his or her political culture. ${ }^{7}$ At the same time, the development of a political culture occurs because of the complexity of its existing values. Thus, people's life is filled by an interaction among different values which creates "political subculture" and in turn will determine the cultural future of the nation. ${ }^{8}$

Based on this theory, this paper is an attempt to deal with several questions concerning the relationship of subcultures and political participation. Is it true that the political culture of the NU elites is a result of different geo-culture and geo-politics? How is the interaction between the local culture and politics built? Does this kind of interaction have any influence on the political participation of the NU elites? What is the nature of the the relationship pattern among the NU elites, especially in fighting for political goals?

Although there are ten subcultures in East Java, this article focuses only on five subcultures, Mataraman, coastal areas, Arek, Madurese, and Pendalungan. This selection is based on the fact that most of the NU elites are concentrated in these five regions.

\section{NU and Politics: A Historical Overview}

The first political movement in Indonesia was Budi Utomo, established in 1908. It symbolized the resurrection of the nation to fight for its dignity. After the establishment of Budi Utomo, the spirit of revival continued to permeate throughout the country. NU was born as a continuation of that spirit.

There were three main reasons for the foundation of NU. First, in a local context, NU was founded as a defensive reaction against the

\footnotetext{
6 Gabriel A. Almond dan Sydney Verba, Budaya Politik: Tingkah Laku Politik dan Demokrasi di Lima Negara (Jakarta: Bumi Aksara, 1990), p. 13.

${ }^{7}$ Ibid.

8 See Nasarudin Syamsudin, "Aspek-aspek Budaya Politik Indonesia," in Alfian and Nasarudin Syamsuddin (ed.), Profil Budaya Politik Indonesia (Jakarta: Gramedia, 1991), p. 23.
} 
reformist activities of Muhammadiyah and Sarekat Islam. ${ }^{9}$ Second, as stated by Alfian, NU was founded as an effort to provide a place for traditional Muslims who were mostly adherents of Sha ischool of Islamic law in the midst of political developments which gave little space for traditional Muslims. ${ }^{10}$

The third reason is that, in a global context, NU was established as a response towards the emergence of the modernist movement in the international arena, which was pioneered by Pan-Islamic groups. After the demise of the Ottoman Empire, which provided protection and support to traditional ulama $>$ Pan Islamic groups began to control Muslim states and discredit groups which had different points of view. ${ }^{11}$ This issue had sparked concerns among traditional ulama> regarding the marginalization of their role, especially after the modernist Muslim groups gained some international support.

All of those reasons formed the starting point of the founding of NU. The forming of the Komite Hijaz (Hijaz Committee) chaired by $\mathrm{KH}$. Wahab Hasbullah was the first step. Komite Hijaz was an embryonic and ad hoc organization established to prepare a special envoy to attend the Congress of Muslims in Mecca. However, before departing to Mecca, and after consultation with several ulama ;it was eventually agreed, on 16 Rajab $1344 \mathrm{H}$. (January 31, 1926), to form an organization called NU The organization was first led by KH. Hasyim Asy'ari. To affirm the basic principle of this organization, Hasyim Asy'ari wrote a book called Qa Asas principles), followed by another book I tiqa Abl al-Sunnab wa al-Jama (the basic tenets of "the People of Sunnah and Group", abbreviated as Aswaja). Both books were embodied in Khittah Nahdlatul Ulama, which was henceforth used as the basic reference for NU members in implementing its thought for social, religious and political purposes.

\footnotetext{
9 Martin van Bruinessen, NU, Tradisi, Relasi-Relasi Kuasa dan Pencarian Wacana Baru, translated by Farid Wajidi (Yogyakarta: LKiS, 1994), p. 17.

10 The opinion of Alfian is quated by Laode Ida, Anatomi Konflik NU; NU, Elit Islam dan Negara (Jakarta: Penebar Swadaya, 1996), p. 9.

11 Ibid., p. 28. From this condition it is then emerged the effort to establish organisation which later to be representative of traditional ulama $>$ in the World Muslim Congress in Mecca.
} 
At the beginning of its establishment, NU emphasised its programs on education and the preaching of Aswaja principles. ${ }^{12}$ Until the 1930s, NU was consistent to work on these issues. However, NU's attitudes then began to change, especially after the issuance of the new ordinance by the Dutch colonial authority (Guru Ordonnantie, 1925) which restricted the movement of religious teachers. The colonial authority also changed marriage laws, an act which seemed deliberately designed to prohibit polygamy, performed the autopsy of the Muslim corpses, and provided greater government subsidies to Christian schools. In general, this condition became the starting point for $\mathrm{NU}$ in general and especially its leaders to become actively involved in the state affairs. ${ }^{13}$ Another of NU's political inclinations can also be observed through its national conference in 1938. At that time, there were several proposals to urge NU's involvement in the political arena through its representatives in the Volksraad. Nonetheless, this proposal was rejected by the conference. ${ }^{14}$

The emergence of its young leader, Wahid Hasyim, who would later be a representative of the Muslim camp during events prior the independence, also marked the involvement of NU in politics. After independence, in 1952, NU became a political party. Furthermore, NU took part in the $1955^{15}$ and $1971^{16}$ general elections and gained significant votes. In 1973. after the New Order regime curtailed political rights, the regime decided to merge Islamic parties into a single party named Partai Persatuan Pembangunan (Unitary Development Party), in which NU was unhappy with its political allies. ${ }^{17}$ Finally, in 1984 NU officially resigned from the political arena.

12 Abl al-Sunnah wa al-Jama was mentioned in NU statute after the national conference in 1979 especially in article 2: NU is based on Islam and aims for upholding Islamic law according to four Schools of Jurisprudence (madhhab: Maliki> Hanafi Syafi'i and Hambalip.

${ }^{13}$ Fealy, Ijtibad Politik Ulama, p. 47.

14 Ibid., p. 48.

${ }_{15} \mathrm{NU}$ gained 18,4\% from the total of national vote. See Alfian, Hasil Pemilihan Umum 1955 untuk. DPR (Jakarta: Leknas LIPI, 1971), p. 54.

16 In the 1971 general elections NU gained 18,5 \% votes. See Ali Haidar, Nabdlatul Ulama dan Islam di Indonesia; Pendekatan Fikih dalam Politik. (Jakarta: Gramedia Pustaka Utama, 1994), p. 176.

${ }^{17}$ Robert W. Hefner, in Andree Feillard, NU Vis a Vis Negara, translated by Lesmana (Yogyakarta: LkiS, 1999), p. xviii. 
This decision was later known as the spirit of the return to the 1926 khittah (original track) of NU in which Abdurrahman Wahid, a son of Wahid, later the president of Indonesia in 1999-2001), was among the initiators. ${ }^{18}$ However, despite declaring that it had retreated from practical politics, the involvement of the NU elites (directly ${ }^{19}$ or indirectly ${ }^{20}$ ) in political arena remained apparent.

In terms of its consistency in the framework of the 1926 khittah, NU experienced great internal turmoil because of the critical political events following the resignation of Suharto from the presidency in 1998. This resignation marked the Reformation era and democratization in Indonesia. As a result, certain members of the NU responded by suggesting the creation a party to accommodate NU interests. The proposal came not only from the party's elites, but also from NU members across the country. ${ }^{21}$ Furthermore, there were thousands of people visiting Abdurrahman Wahid, the then chairman of NU Central Board (PBNU) while he was sick. All of them requested the central board of NU to establish a political party. Wahid then responded by saying that NU members needed to have a space in political arena. ${ }^{22}$

Consequently, on 3 June 1998, the central board of NU formed tim $\operatorname{lima}^{23}$ (the committee of five). Their objective was to examine the likelihood of fulfilling the demands of the NU members to create a political party. On 20 June 1998, NU formed another team to assist ${ }^{24}$

\footnotetext{
${ }^{18}$ Ida, Anatomi Konflik, p. 26.

19 Many NU members participatee in politics as members of political parties. When that happened, they found it difficult to perform both roles. See Zainal Abidin Amir, Peta Islam Politik Pasca Soeharto (Jakarta: LP3ES, 2003), p. 109.
}

${ }^{20} \mathrm{NU}$ is known for its cultural politics, civil society empowerment, strengthening local groups based on pesantren network, then increasing its bargain power to the government. In this situation, NU will have formidable position in the society. See Muhammad AS Hikam, Demokrasi dan Civil Society (Jakarta: LP3ES, 1996), p. 234.

${ }^{21}$ Amir, Peta Islam Politik, p. 109.

22 Asmawi, PKB; Jendela Politik Gus Dur (Yogyakarta: Titian Ilahi Press, 1999), p. 6.

23 Team five was chaired by KH. Ma'ruf Amin (Rais Syuriah PBNU), KH. M. Dawam Anwar (Katib Am PBNU), Dr. KH. Said Aqiel Siradj (Vice Katib PBNU), HM. Rozy Munir, ME., M.Sc. (Chairman of PBNU) dan H. Akhmad Bagja (Secretary General of PBNU). See Amir, Peta Islam Politik, p. 111.

${ }^{24}$ Assitants to Team five were Arifin Junaedi (chairman), H. Muhyidin Arubusman, HM. Fachri Thaha Ma'ruf, Lc., Drs. H. Abdul Aziz, MA., Drs. H. Andy Muarly 
tim lima. Through meetings and discussions, it was decided on 23 July 1998 that NU should initiate the birth of a new political party called Partai Kebangkitan Bangsa (The National Awakening Party). In the following year, PKB participated in the 1999 general elections and received a significant number of votes. ${ }^{25}$ This success was repeated in the 2004 general election. The PKB once again obtained a large number of votes, ${ }^{26}$ even though it decreased from the 1999 general election.

The History of NU and political parties culturally affiliated to it cannot be separated from the role of 'ulama's and other figures from pesantren (traditional Islamic boarding schools). ${ }^{28}$ 'Ulama $>$ (Kiai, in Indonesian) is a figure identical with NU because NU was established by Kiais. ${ }^{29}$ In addition, kiais role as community leaders, teachers, as well as preachers, made them special for NU members.

Kiais, in the NU political tradition, can be classified as an elite group. ${ }^{30}$ Not only do the kiais become the vote getters, but they also have political power. Some kiais are politicians, from political party leaders to members of parliament. The involvement of NU 'ulama politics has had a long history since the early period of Masyumi

Sunrawa, HM. Nasihin Hasan, H. Lukman H. Syaifuddin, Drs. Amin Said Husni, and A. Muhaimin Iskandar. See Ibid., p. 112.

$25 \mathrm{PKB}$ was in third place with 13.336.982 votes, the first was PDIP and the second was Golkar. Muhammad Asfar, Pemilu dan Prilaku Memilih 1995-2004 (Surabaya: Pustaka Eureka and PusDeHAM, 2006), p. 118.

${ }^{26}$ Ibid., p. 127.

27 According to Horikoshi, the position of kiais is different from the ulama $\rightarrow$ in Java.

'Ulama \ave a deep knowledge in religion, but they do not have charisma or influence to the prople, while the kiais have reasonable religious knowledge but their charisma and infleunce is much bigger. However, Horikoshi stated that most of kiais have a fairly extensive religious knowledge. See Hiroko Horikoshi, Kiai dan Perubahan Sosial, transl. by Djohan Effendi and Muntaha Azhari (Jakarta: LP3ES, 1987), p. 235.

${ }^{28} \mathrm{NU}$ board usually consists of kiai, relatives of kiai, alumni of pondok pesantren, or islamic education institution which has religious relation with NU. See Fealy, Ijtihad Politik Ulama, p. 52.

29 Although not all kiai own Pondok Pesantren such as K.H. Muchit Muzadi in Jember, but most of them have Pondok Pesantren.

${ }^{30}$ Kiai is categorized as elite because charaterized as subjugete other people with his ability. See Geraint Parry, Political Elites (London: George Allin and Unwin Limited, 1969), p. 46. 
(Majelis Syura Muslimin Indonesia) development just years after the independence of Indonesia. Moreover, many pesantren alumni are also involved in politics.

\section{East Java in the Context of Culture and Politics; Hybridization and amalgamation}

In the story of the NU elites in East Java, a kind of hybridization has taken place, from a homogeneous society to a heterogeneous one. This has happened because of long and intense cultural interactions. According to Pieterse, hybridization is a way in which a certain form of culture is released and recombined into new forms, which refer to the contents of each culture among localities and also the transition between the localities to trans-locality culture. ${ }^{31}$ In addition, these groups interact, communicate, and build their own systems. In the process of interaction a dialogical process of meaning occurs where the messages are contested, integrated, or interchanged. Subject and object are mutually communicated. Friedman mentions this process as a form of "attribution meanings." 32

Furthermore, Pieterse divides hybridization into two forms, structural and cultural. Structural hybridization is a combination process which produces organizational options for the community, while cultural hybridization distinguishes various cultural responses that range from assimilation, segregation, to hybridization which destabilizes and obscures cultural barriers. This point results in a conflict and the emergence of an 'imagined community'. ${ }^{33}$

In the context of Islamic societies in East Java, hybridization is both structural and cultural. Mataraman Islam, which stretches from the western part of Jombang to the western part of Madiun, is a mixed culture of Hindu, Javanese and Islam. It has a different character and culture from other Muslim societies in East Java. The deep influence of the Islamic Mataram in community is undeniable. According to Woodward, ${ }^{34}$ areas in these regions are unique not because they

\footnotetext{
${ }^{31}$ JN. Pieterse, "Globalization as Hybridization," in M. Fetherstone, et al. (eds), Global Modernities (London: SAGE Publication, 1995), p. 68.

32 J. Friedman, "Global System, Globalization and The Parameters of Modernities," in Featherstone, Global Modernities, p. 70.

33 Pieterse, "Globalization as Hybridization," p. 208.

34 Mark R. Woodward, Islam Jawa; Kesalehan Normatif versus Kebatinan, translated by Hairus Salim HS (Yogyakarta: LKiS, 2006), p. 354.
} 
maintain the pre-Islamic culture and religion, but because the concepts of Sufism, mystical path, and human perfection are practiced in the formulation of an imperial cult.

Hence, texts, myths and other ideological statements have granted privileged access to the organization. A convincing example can be seen through a Javanese theory of ratu adil (messiah) common to the Mataraman NU elites. Theoretically, the king of Mataram is a perfect human being guided directly by the will of God, and able to ensure prosperity, power and spirituality for all of his people. This concept has an influence on Javanese culture, although this doctrine is not widely held. However, nowadays the Mataraman people generally consider that the instability which has been happening is because the king does not meet the ideal criteria. The movement of ratu adil has become a familiar practice.

Long before the structural and cultural hybridization in Mataraman, Islam first touched the north coast communities of East Java through trade and business. ${ }^{35}$ People in coastal cities such as Surabaya, Gresik, Lamongan and Tuban not only created social contacts, but also a space for social change and reformation. Tolerance then became a common social belief. . Thus, the effort to embrace new beliefs could be made virtually without social conflict.

In the context of Islam in the coastal areas, there took place a cultural hybridization of Majapahit into Islamic culture was due to the economic dependence of the rulers of Majapahit on Muslim merchants of the north coast who had an international reputation. Despite this, Islam in East Java's coastal areas can be seen as more orthodox compared to Mataraman Islam because of the direct contact with Islam in the Middle East. Many different terms have been coined to describe Islam in the region: "Javanese Islam" (Geertz) which is syncretic, ${ }^{36}$ "multifocal Islam" (Beatty), "local Islam" (Mulder), ${ }^{38}$ and

\footnotetext{
35 Muhammad Habib Mustopo, Kebudayaan Islam di Jawa Timur (Yogyakarta: Penerbit Jendela, 2001), pp. 133-140.

${ }^{36}$ Clifford Geertz, Abangan, Santri dan Priyayi dalam Masyarakat Jawa (Jakarta: Pustaka Jaya, 1981), p. 175.

37 Andrew Beatty, The Varieties of Javanese Religion (Princeton: Princeton University Press, 1999), p. 62.

38 Niels Mulder, Agama, Hidup Sehari-Hari dan Perubahan Budaya (Jakarta: Gramedia Pustaka Utama, 1999), p. 3.
} 
"acculturative Islam" (Woodward). ${ }^{39}$ Nur Syam creates the term "collaborative Islam" to illustrate the features of Islam in coastal areas, claiming that north coast communities are the first community in Java who converted to Islam. ${ }^{40}$ This trend creates a dichotomy between orthodox Islam and collaborative Islam which also represents the dichotomy between coastal Islam and inland Islam. The basic characteristic of coastal Islam is obedience in practicing religious teaching. However, this religious commitment is not necessarily reflected in politics. The cultural influence of the coastal areas is very strong in shaping the political rationality of the local community.

Long and intense interactions between coastal residents and the metropolitan culture of Surabaya formed a new subculture known as "Arek" community. Geographically, this community stretches along the eastern section of the Brantas River, from Pare Kediri to Jembatan Merah in Surabaya. Jembatan Merah is the "melting pot" of Arek culture. In an interview with Akhudiat, Jembatan Merah, and its surrounding areas, was referred to as the icon of Arek where many cultures of East Java met during the $19^{\text {th }}$ and early $20^{\text {th }}$. For example, Chinese people settled on the east side, Arab and Malay people on the north side, and Javanese people on the south side.

According to Akhudiat, ${ }^{41}$ "Arek" culture is the cultural hybridization of Majapahit, Islam, Mataram, and modernity (shaped by the Dutch). The influence of Majapahit can be seen from the use of the term "Adipati" (governor) by Sunan Ampel as the leader of Surabaya in the late 1400s, not "king" as used in Mataram. This is a tribute to Majapahit. ${ }^{42}$ Raden Rahmat or Sunan Ampel has a kinship relationship with Majapahit, through her aunt, Darawati, who married Kerta Wijaya. Raden Rahmat had orders to secure Ampel Denta Surabaya on the north coast in the 15th century, and later gained the title "Sunan Ampel". Before Raden Rahmat's leadership, Surabaya was ruled by a Muslim Majapahit official named Arya Lembu Sura in Glaga Arum (Peneleh) in the late $14^{\text {th }}$ century, who was succeeded by Raden Rahmat as his grandson in law in the mid $15^{\text {th }}$ century and then by the

\footnotetext{
${ }^{39}$ Woodward, Islam Jawa, pp. 364-5.

${ }^{40}$ Nur Syam, Islam Pesisir (Yogyakarta: LKiS, 2005), p. 91.

41 Akhudiat, Masuk Kampung Keluar Kampung; Surabaya Kilas Balik. (Surabaya: Henk Publica, 2008), p. 115.

42 Akhudiat, Interview, 10 Nopember 2008.
} 
descendants of Sunan Ampel in the 17th century. ${ }^{43}$ Meanwhile, Mataram started to control Surabaya at the end of Prince Pekik's regime as the Mayor of Surabaya in the middle of $15^{\text {th }}$ Century, which marked Mataram cultural influences in Surabaya. It is in this coastal Javanese culture that Islamic values influenced the formation of santri character in Arek culture. The ludruk performance by people of Surabaya was often used as social criticism against the government. ${ }^{44} \mathrm{~A}$ Surabaya ludruk iconic figure in that decade, Cak Durasim, often launched such sharp criticism.

The meeting of three cultures resulted in a new hybridization, namely the hybridization of collective identity. Using Ridjal's term, ${ }^{45}$ the symbolic cultural identity of Majapahit, north coast areas, Mataraman, and Islam have been altered and "de-regionalized". People in the north coast tend to be pious, just as those in Mataram have more syncretic styles. The teachings of Islam, brought by the Adipati Surabaya, Sunan Ngampel, and modern culture brought by the Dutch lead to the emergence of a new subculture called "Arek" culture. The characteristics of Arek culture are religious, nationalistic, egalitarian, and tolerant. The combination of these elements into a collective culture had an impact on political behavior. It was in this culture, which spread from Kediri, Jombang, Malang, to Surabaya, that NU and its elites originated.

Meanwhile, in the eastern part of East Java there are two cultures and subcultures; Madurese and Pendalungan. This hybridization began with a meeting of the culture of Majapahit, Mataram and north coast within Madurese community. In term of its ecological background, Madura consists of dry and less productive land. According to Kuntowijoyo, ${ }^{46}$ ecological factors deeply influence the shaping of Madurese culture, which is generally attributed as temperamental and religiously fanatic. He stated that Madurese people are not unified by

43 Akhudiat, Masuk Kampung Keluar Kampung, pp. 115-6.

44 Siti Zuhro, et al.., Demokrasi Lokal; Perubaban dan Kesinambungan Nilai-Nilai Budaya Politik Lokal di Jawa Timur, Sumatera Barat, Sulawesi Selatan dan Bali (Yogyakarta: Penerbit Ombak, 2009), p. 43.

45 Tadjoel Rizal Bdr, Tamparisasi Tradisi Santri Pedesaan Jawa (Surabaya: Yayasan Kampusina, 2004), p. 343.

46 Kuntowijoyo, Perubahan Sosial dalam Masyarakat Agraris Madura 1850-1940 (Yogyakarta: Mata Bangsa, 2002), p. 75. 
social dependence as in Java. Houses in Madura are also set apart from one another, different from in Java where people tend to live in clusters of adjacent buildings in residential areas. It is in this social background that religion plays a big role in Madura. Based on this view, lacking social dependence, people of Madura are often socially dependent upon religious clerics or kiai. As a result, they have a tendency to become religiously fanatic.

In addition, there is a philosophy of Madurese people known as buppa', bubbu, guru, ratob (father, mother, teacher, king) which explicitly suggests the existence of strong adherence to the four components. In their philosophy, the four components are equal; father and mother are the ones who give birth, the teacher is the one who introduces learners to knowledge, and the king gives protection and security. ${ }^{47}$

In addition to those living on the island of Madura, in the eastern part of East Java there are large Madurese communities who migrated to the area. They inhabit the region of Banyuwangi, Jember, Situbondo, Bondowoso, Probolinggo, Pasuruan, and Lumajang. The Dutch population census conducted in 1930 showed that $55 \%$ of the population was Madurese. This large population could not be separated from the migration of 1806 when the Dutch opened the plantation of tobacco, coffee, rubber, and cocoa in Jember which required a large number of laborers. Thus, the migration created a new diaspora of Madurese in Java.

According to Ayu Sutarto, 48 culturally, there are differences between Madurese people living in Madura island and those inhabiting the eastern parts of East Java. This difference is partly because of the latter's long interaction with Osing culture of Blambangan Hindu and 'native' people of eastern parts of East Java. This interaction created a new culture called "Pendalungan". Pendalungan is a new subculture mix between Madurese and Javanese in Blambangan. In terms of language, most of the people of Madura still speak Madurese language but mixed with Javanese. Some speak Javanese with a Madurese accent.

\footnotetext{
${ }^{47}$ Hary Yuswadi, "Budaya Pendalungan," in Ayu Sutarto and Setya Yuwana Sudikan (eds), Pemetaan Kebudayaan Propinsi Jawa Timur; Sebuab Upaya Pencarian Nilai-Nilai Positif. (Jember: Biro Mental Propinsi and Kompyawisda Jatim, 2008), p. 54.

48 Ayu Sutarto, Setya Yuwana Sudikan (eds), Pemetaan Kebudayaan Propinsi Jawa Timur; Sebuah Upaya Pencarian Nilai-Nilai Positif Jember: Biro Mental Propinsi and Kompyawisda Jatim, 2008), p. v.
} 
In Pendalungan we can trace some pre-Islamic rituals of Osing culture, for instance Hindu's tradition of offerings, Tola' bala' and ruwat. These rituals are still visible in many places, especially from the older generation. However, cultural and structural hybridization cannot be denied in the history of Madurese living in Java, who then became Pendalungan. This means that there is crossbreeding, especially in terms of the changing of social roles in Pendalungan multiethnic society. There is also cultural hybridization in Pendalungan in the form of mixture between various languages and traditions which form a 'new culture'. Currently, for example, there are many Madurese people who choose to become government employees, an occupation that was previously uncommon among Madurese. ${ }^{49}$

Furthermore, in addition to performing Javanese art shows in Madurese language, there is also cross-ethnic involvement by Javanese and Madurese in Chinese and Arabic art shows, without changing the format of the show and the language. For example on Chinese Lion Dance and Liang Liong in Jember, there are many performers, both dancers and musicians, who are Madurese and Javanese. This condition runs parallel to Arabic music of Gambus and Osing musical tradition of Kendang Kempul and Janger whose performers are Madurese and Javanese. This evidence clearly shows that, despite hybridization, there is 'nothing entirely authentic'. In other words, there is an awareness and personal willingness to participate in the other ethnic group's cultural identity either because of economic motivation or cultural responsiveness. Nonetheless, it does not necessarily mean they are stripped of their own cultural identity and ethnic origin.

In addition to the personal oriented hybridization, there is also hybridization that produces new art forms, such as Can-Macanan Kadduk arts and Patrol music in Jember, Singo Ulung and Puppet Kerte in Bondowoso. Can-macanan Kadduk is an art form originated from farmer practices depicting their activity to keep wild animals thieves away from their field. ${ }^{50}$ It is a combination between Osing Barongan, Chinese Lion Dance and Javanese Music. Despite its different background, Singo Ulung is very similar to the Can-Macanan Kadduk, although its costumes and dance are more elaborate because of the involvement of professional choreographers. Meanwhile, Puppet

\footnotetext{
49 Akhudiat, Interview, 10 Nopember 2008.

50 Syamsul Gentong, Interview, 23 Nopember 2007.
} 
Kerte, made of flat wood (such as krucil puppet), is a puppet show telling stories about everyday life. ${ }^{51}$

The identity of the new culture constructed by these two dominant communities is no longer confined to a particular ethnic culture, but is strongly influenced by the size of the dominant community in its cultural and social areas. Madurese people who are characterized as pious, high-tempered, expressive, and paternalistic are able to manage their community in Pendalungan. Correspondingly, the Javanese are able to communicate with them. The identity of this culture is a compromise of two dominant cultures which are successful in cooperating in the sense of forming a multicultural relationship.

The following scheme explains the formation of cultural hybridization of Pendalungan subculture:

Table 1: The Cultural Hybridization of Pendalungan Subculture

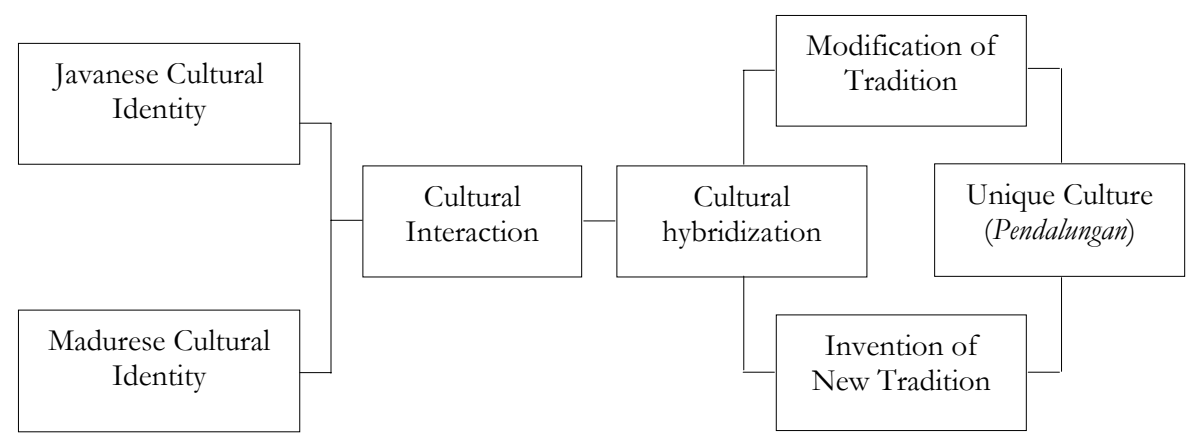

Source: Hary Yuswadi, "Budaya Pendalungan; Multikulturalitas dan Hibridasi Budaya Antaretnik," in Sutarto and Setya Yuwana Sudikan (ed.), Pemetaan Kebudayaan Propinsi Jawa Timur, p. 60.

The relationship between cultures which stimulates the creation of a new one (subculture) can be understood as the reality of habitus, habit and habitat relationship in a linear fashion. The relationship between cultures which are mediated by individuals and groups is one of mutual strength. In the concept of habitus, each individual has a cognitive cultural structure that has been established, which originates from

${ }^{51}$ Rahardjo, "Pendalungan; Periuk Besar". 
experience and knowledge about his or her culture. ${ }^{52}$ Habitus enters in the space which is conceived of having a relationship with one another. In this social space, individuals with their habitus communicate to other individuals in various social realities that produce actions in accordance with the sphere and capital he has. ${ }^{53}$ Bourdieu states that "with habitus, individuals can understand realm and capital, and individuals can also question the structure, and even change it." 54 This means that the relationship between cultures held by individuals is likely to change due to the need to complement and improve the culture. By using the concept of habitus, shifts and changes, among cultural groups in East Java can be understood as natural processes, which take place as a result of mutual enforcement among the cultures.

On the other hand, there are some unspoken rules regarding the relationship between individuals. Rules which usually work as a mode and emerge into what Bourdieu called as "symbolic violence". Symbolic violence is very subtle violence, which is imposed on social agents without inviting resistance; instead, it invites conformity because it receives social legitimacy. Language, meaning, and the symbolic systems of the regime are embedded in individual thought through a hidden mechanism. ${ }^{55}$ It can be observed, for example, in the use of language, terminology, or culture within in society. In many ways, it is unnoticed that violence through language can be seen i.e. the Arek language included in Pendalungan and Coastal tradition. Moreover, coastal and Mataraman language are included in Arek language. Symbolic violence through language is unconsciously gained social legitimacy due to the very strong relationship. Bandura calls this condition "strengthening each other's relationship." 56 Borrowing Christian Rahardjo's expression, ${ }^{57}$ East Java can be seen as culturally a "big pot" where several cultures eventually formed a new sub-culture

\footnotetext{
52 Pierre Bourdieu, Outline of a Theory of Practice (Cambridge: Cambridge University Press, 1977), p. 13.

53 Pierre Bourdieu, Distinction (Cambridge: Cambridge University Press, 1984), p. 101.

54 Ibid.

55 Richard Harker, et al. (eds), Habitus X Modal + Ranah = Praktik (Yogyakarta: Jalasutra, 2008), p. 116.

56 A. Bandura, Sosial Learning Theory (New Jersey: Englewood-Cliffs-Pretice Hall Inc., 1977), p. 124.

${ }^{57}$ Rahardjo, "Pendalungan: Periuk Besar".
} 
as a result of the interactions and changes in society. This large pot also influences the pattern of political participation which is based on the new culture.

Geopolitical and cultural hybridization is one important factor that creates East Java's dynamic and harmonious political community . For example, in the context of culture, on the one hand the old culture is maintained as a form of respect; on the other new plausible ideas and cultures are also accepted. This condition is mirrored in the political sphere. For example, when speaking of the Pendalungan community as a fusion process, we can also speak of it in the context of a multicultural society. This is because, in addition to the discovery of the combination that produces new culture, the respective cultural groups are still maintained. Further, the communities still interact with each other and preserve their individual identities and cultures. Bourdieu calls this condition a form of reassurance to the established cognitive structures. 58

In addition, this confirms Pieterse's thesis about solid ethnic identity which remains intact amidst the hybridization process. A good example of this is Jember regency, as revealed by Christian Rahardjo, ${ }^{59}$ in which the difference between thesouthern and northern areas in that regency is easily seen in their cultural activities. As a product of colonial-style ethnic segregation, the ethnic Javanese who inhabit the southern areas (i.e. sub-districts of Ambulu, Wuluhan, Balung, Puger, Gumukmas, Kencong, Jombang, Umbulsari, and Semboro) still practice Javanese culture both in terms of language, arts, and other customs. The Javanese community in Ambulu and Wuluhan, for example, preserve the Reog derived from their ancestors in Ponorogo, a regency of Mataraman community in southern East Java. In addition, almost all the communities in the south tend to be fond of Wayang Kulit, Jaranan, and Campursari. In terms of education, they still send their children to formal education, though there are also some Islamic boarding schools in that area.

In northern areas, in contrast, people still preserve their Madurese culture. Madurese language is used in everyday live in sub-districts of Arjasa, Jelbug, Sukowono, Kalisat, Sumberjambe, Ledokombo, Mayang, and some parts of Pakusari. In addition to ludruk which is

\footnotetext{
${ }^{58}$ Harker, et al (eds), Habitus X Modal, p. 120.

${ }^{59}$ Rahardjo, "Pendalungan: Periuk Besar".
} 
modified into Madurese-style, they also enjoy traditional art performances such as hadrah which has a Madurese influence. They are also fond of pengajian (religious speeches) because through this activity they can meet lorab (clerics) or gus (sons of clerics) who are considered to able to bring blessings for them. Meanwhile, in the central part of city and suburbs, ethnic Chinese are successful in doing business as well as preserving their traditional art performances such as Lion dance and Liang Liong. During the Chinese New Year festival, these art shows are performed publicly on the streets of Jember.

Even though the younger generation tends to use Indonesian and Javanese with a Chinese accent, some people in the Chinese community also speak Mandarin. Since the majority of Chinese communities are Protestants or Catholics many of them send their children to schools which are managed by churches or Protestant or Catholic foundations. Meanwhile, the Arabs maintain their identity through marriage by not allowing the marriage of an Arab with a person of other ethnic groups. They also preserve their traditional music known as gambus.

That is yet another characteristic of Pendalungan. A cultural community that is considered to have an acculturation of Java and Madura, has "a multicultural orchestra" that runs harmoniously and dynamically. Although they are frequently seen as generating a hybrid cultural product of Pendalungan, they still recognise their own history in the form of maintaining the identity of their ethnic culture. Those who live their lives in "the huge tub", residing in the regencies of Bondowoso, Situbondo, Probolinggo and Lumajang, have developed a form of tolerant multicultural community.

Cultural dialectic factors have a strong influence on the emergence of a new culture through interaction. The core of this interaction process turns individuals into community members who learn the community culture and fully participate in the community. Where social circumstances, allow human beings to interact, their attitudes towards their social circumstances and also their behaviors and actions tend to strengthen one another. With their own idea of their established cultural identity within their developing cognitive structure (habitués) people tend to produce behaviors and actions (habits) as a reaction to their social circumstance (habitation). Simultaneously, habit influences habitation. Furthermore, the transformed habitation demands the development of new habitation, and thus it produces a 
new habit and so forth. The relationships among these components are such that each strongly influences the others. These are what Bandura $^{60}$ calls "interlocking determinants" and Thompson calls "compatibility conditions."

\section{NU Elites of East Java and Multiethnic Political Participation}

The Muslim people of East Java are mostly NU members. In addition to the influence of cultural hybridization which affects the behavior, attitudes and patterns of the political elites, we can also find cultural, social and political change in a very broad scope shaping the pattern of NU elites' political participation. This condition happens because of new thinking, especially about the concept of Aswaja (Sunnism).

The dynamics of the NU elites' political participation can be seen through different approaches, such as the geopolitical changes arising from the penetration of new cultures and subcultures through hybridization. It can also be seen through shifts in the organization and its social political factors. Another factor is the emergence of new thinking in Islamic doctrines as stipulated in the basic concept of Aswaja. The basic concept has stimulated a fragmentation of political attitudes among NU members. As Table 2 shows, the hybridization and geopolitical changes form the participation pattern of the NU elites in East Java.

The political participation of the NU elites in East Java can be seen as an orchestra with its diversity of musical instruments joined into one dynamic rhythm. Each has its own characteristic patterns and behavior. What we might see on the surface seems to be chaos, but in reality it is a reflection of beautiful and dynamic political culture.

${ }^{60}$ Bandura, Sosial Learning Theory, p. 124.

62 Friedman, “Global System, Globalization”. 
Table 2: Geo-cultural, geo-politic and hybridization of NU political elites in East Java

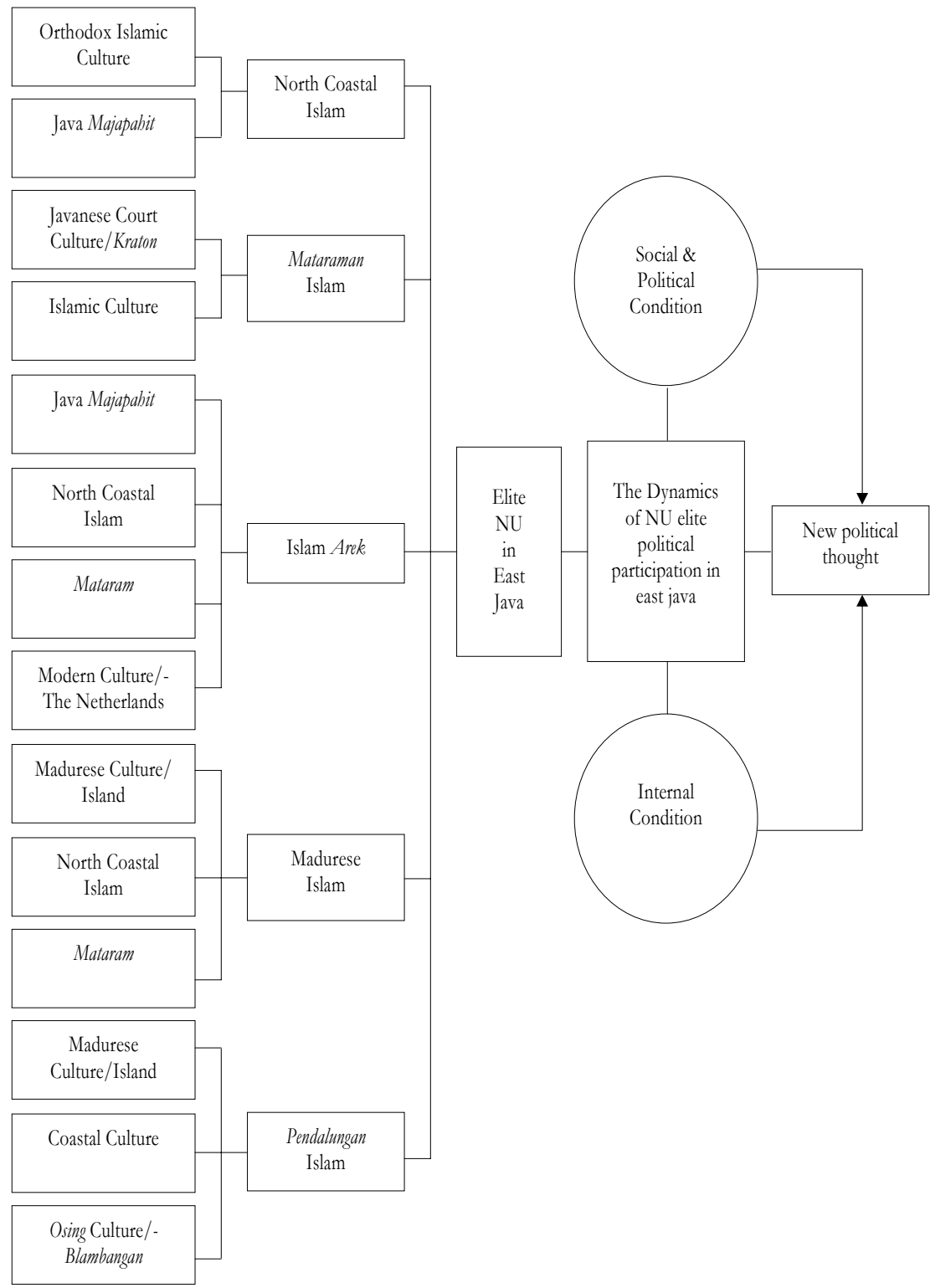


This multicultural orchestra also has an impact on the political orchestra. The geo-political conditions in Madura, which position the kiai as unifiers, also occur in the Pendalungan community. The function of kiai as religious leaders and political figures is conceived as a compulsion that is still believed and accepted by the local community. Those prominent figures that possess political power are the kiai of Madurese or Pendalungan offspring. The late Kiai Achmad Shiddiq, the late Kiai Yusuf Muhammad, Kiai Khotib Umar, the late Kiai As'ad Syamsul Arifin, Kiai Sofyan, Kiai Fawaid, the late Kiai Wahid Zaini, Kiai Mutawakil Alallah, and Kiai Mahmud Zein are all examples of such personalities.

Meanwhile, in the north coast areas, though kiai have a fairly considerable influence and power, theMuslim community in those areas are more rational in politics. The kiai-santri (teacher-student) relationship is more flexible. In politics, this means that the political preference of kiai is not necessarily followed by santri. It is stated in Friedman's thesis that each figure is viewed as human being that has objectives, and his or her actions are aimed at those objectives and are only applicable in that region. ${ }^{62}$ Although the position of kiai as religious figure is very authoritative, he is unable to press his congregation to follow his political preference. In the history of parliament elections, the political party supported by kiai has not always had a landslide victory. This differs from Madurese and Pendalungan areas, where the kiais political preference strongly influences the political tendency of the santri. For instance, after the move of Kiai Fawaid of Situbondo from the PKB to the PPP, following his dispute with Gus Dur (Kiai Abdurrahman Wahid), the PPP (which only got 1 seat in the 1999 elections), obtained as many as 7 seats in the 2004 local parliamentary elections. However, in general the PKB remains the party of NU members, although the victory of the PKB in Pendalungan and Madura is usually more convincing than in north coast areas.

Meanwhile, in the more heterogenic, Arek region, NU's political orchestra show is more dynamic and euphonious. The culture of santri and modernist are integrated into one political culture domain; so there is no permanent winner. Religious and nationalistic spirits are integrated to create the dynamic political orchestra of the Arek community. Thus, sometimes the religious group represented by the $\mathrm{PKB}$ is victorious; in another period the nationalist PDIP comes out 
on top. The case of Surabaya is a clear example. In the 1999 parliamentary election, the PDIP won, whereas in 2004, the PKB was victorious. This political dynamic is found in nearly all regions which are categorized as Arek, from Surabaya all the way to Kediri.

Another manifestation of this political elite orchestra in the context of NU is the Islamic boarding schools in Jombang. Four historically related large Islamic boarding schools are Tebuireng, Tambakberas, Denanyar, and Peterongan. Since the New Order regime, the political preferences of the NU elites affiliated to those boarding schools has tended to be different. The Tebuireng families are active in the PPP, PKB and PKNU; Tambakberas families tend to join the PKB, and recently the PPP and PDIP, particularly Kiai Hasib, who is currently a member of the House of Representatives from the FPDIP. Peterongan has long been tied to Golkar through the Kiai Musta in, although some figures are also active in the PKB, PPP and PAN. Meanwhile, Denanyar is still connected to the PKB through the family of Iskandar, who has a large influence, both at a national and local (Jombang) level. These conditions back up the view of Tadjoer Rizal, in his research in Sumber Arum Jombang, who states that cultural hybridism may truly have an impact on other aspects of transformation, as well as on the complicated political culture of Arek (including in Islamic Boarding Schools culture). It may also cause deviations in political preference due to the strength of cultural hybridism into political sector.

In the Reformation era from 1998 up to the present, the political tendencies of the traditional coastal community and the Madurese, both in Madura island and Pendalungan, did not go beyond the political basis of the PKB. Meanwhile, those who broke with Gus Dur tend to back the PPP, which has traditionally had a relationship with the NU elites. Besides, in Arek tradition, transformation does not only occur in kiai-santri relationship but also goes beyond the mono-political NU tradition that has meant it was hard to escape from the traditional politic circle. As stated by Asfar, while conducting research in Jombang, he addresses a transformation from traditional to rational. ${ }^{63}$ In this context, the political choice of Kiai Hasib of Tambakberas to PDIP and Gus Luqman of Peterongan to PAN naturally and traditionally goes beyond political transformation as stated in Asfar's

${ }^{63}$ Asfar, "Pergeseran Otoritas Kepemimpinan Politik Kiai", p. 77. 
study. Arek culture can be analyzed using Emerson's Rational Exchange Theory that focuses attention on the benefit gained from and contribution given in the process of social interaction. ${ }^{64}$ Rationally, people will act when they derive benefit from their actions. The role of Islamic boarding schools' elites in this case traditionally is understandable since they appear to benefit from the transaction.

Meanwhile, in Mataraman tradition, the political orchestra tends to be static. The influence of Mataram and Sufism embraced by the Keraton is dominant compared to regions in East Java. Sufism, the typical characteristic of the Keraton, is used to explain, organize and give value to various aspects of life. All of these are in line with what Martin calls a sub-textual assumption, ${ }^{65}$ the subject itself being the series of basic interpretations in Java and the Muslim world as a whole. However, in the Mataraman Muslim community, the way they interpret and implement those axioms has an impact on how culture, politics and religion are perceived.

This interpretation process generates two basic forms of religiosity, each of which has a wide series of multiple variants with personal, class-based and regional characteristics. In general, Javanese Muslims believe the rites of life such as circumcision, marriage and bereavement ceremony should be held in accordance with Islamic law, yet they must comply with other aspects of pietism that are freely chosen. In these two cases, according to Woodward, the implementation of the microand macro-cosmos into cosmologist, religiosity, social and politics thoughts transform the character of Javanese mystical Sufism. ${ }^{66}$ In general, Sufism is a private devotion in Islam. Its focus is the relationship between an individual mystic and his or her God. In Mataraman region, the structure of this mystical ideology plays a role in social thoughts and traditional politics.

One of the reasons the NU elites which tend to affiliate with the $\mathrm{PKB}$ and PPP do not completely occur in Mataraman region, is because there is this micro- and macro-cosmos implementation in real life (politics), particularly Sufism. Geertz states that the form of pietism practiced by priyayi or abangan Muslims (to distinguish from pesisir

\footnotetext{
${ }^{64}$ Friedman and Michael Mechter, The contribution of Rational Choice, p. 202.

65 As quoted by Asep Saiful Muhtadi, Komunikasi Politik. Nabdlatul Ulama' Jakarta: LP3ES, 2004), p. 237.

${ }^{66}$ Woodward, Islam Jawa Kesalehan Normatif.
} 
[north coastal] santri, Arek, and Madurese) has very broad personal and regional variants. ${ }^{67}$ The distinction finally depends on individual interpretation, two cases that tend to merge into one another. The function of kiai in daily life is mostly played out in a religious aspect through thripah (Sufi brotherhood) practices/rituals. Meanwhile, their political functions tend to be more personal and benefit-oriented. .

The fact that geo-cultural and geo-political considerations contribute to the tendency of political preference can be seen from parliamentary elections from 1955 up to 2004. In fact, culture and ideology, which play an important role in determining the political participation of the East Java community, cannot be neglected. The cultural and ideological factors (particularly the so called Islam supporters and Nationalists) can be easily observed from the results of these parliamentary elections over the years. In the 1955 parliamentary election in which 39 parties competed, NU and Masyumi both highly dependent on the Muslim communities of East Java, were the major political powers. In contrast, in the faction of non-religious parties, the action of PNI (Indonesian Nationalist Party) and PKI (Indonesian Communist Party) also had a great influence. The result of the 1955 parliamentary election positioned these four parties as winners of a significant share of the votes. In this election, the largest shares of votes were gathered by the NU3,370,000 votes.or $34.1 \%$ of the 9 million total electorate. With that large proportion, NU gained 20 legislative seats or $31.7 \%$ of the total 63 seats. On the other hand, the PNI and PKI competed fiercely with one another for second position. The PKI was able to gain $23.3 \%$ of votes and obtained 14 seats. Meanwhile, PNI got $22.8 \%$ or 14 seats and Masyumi received $11.2 \% .{ }^{68}$

Of those four big parties, it seems that the power of Islamic and non-Islamic parties were in close competition in East Java. If compiled, the votes collected by the NU and Masyumi party dominated 45.3\%, meanwhile PNI and PKI reached 46.1\%. Yet, if viewed from the distribution of votes based on geographical position, Islamic-based parties dominated the eastern part of East Java. They dominated 'Tapal Kuda' (horse shoe) regions such as Bondowoso, Situbondo, Banyuwangi, Jember, Probolinggo, Pasuruan, Sidoarjo, Gresik, Lamongan, Surabaya and Madura. In this region, Surabaya was

\footnotetext{
${ }^{67}$ Geertz, Santri, Abangan, Priyayi, p. 173.

${ }^{68}$ Kompas, 8 July 1971.
} 
the sole area that was not dominated by NU. In contrast, the western parts of East Java such as Bojonegoro, Tuban, Madiun, Ngawi, and Magetan up to the southern part of East Java were dominated of PNI and PKI. ${ }^{69}$

Table 3: The Result of the 1955 East Java Parliamentary Election

\begin{tabular}{lll}
\hline Parties & $\begin{array}{l}\text { Outcomes } \\
(\mathbf{0})\end{array}$ & $\begin{array}{l}\text { Winning concentration } \\
\text { (Party Basis) }\end{array}$ \\
\hline NU & $34.1 \%$ & $\begin{array}{l}\text { Situbondo, Probolinggo, Pasuruan, Sidoarjo, } \\
\text { Surabaya, Gresik, Pasuruan and Madura }\end{array}$ \\
PKI & $23.3 \%$ & $\begin{array}{l}\text { Blitar, Nganjuk, Bojonegoro, Tuban, Ngawi } \\
\text { PNI }\end{array}$ \\
$\begin{array}{lll}\text { Blitar, Nganjuk, Bojonegoro, Tuban, Ngawi, } \\
\text { Madiun, Magetan }\end{array}$ \\
\hline
\end{tabular}

Source: Kompas, 8 June 1997 and 10 February 2004; Research and Development Division of East Java Kompas; www.situsjatim.com; Moch Nurhasim, "Pengaruh dan Kekuatan Kiai dalam Rekrutmen Politik," in Syamsudin Haris (ed.), Pemilu Langsung di Tengah Oligarki Partai; Proses Nominasi dan Seleksi Calon Legislatif Pemilu 2004 (Jakarta: Gramedia Pustaka Utama, 2005), p. 31; Asfar, Pemilu dan Prilaku Memilib; Iskandar Ritonga et al., "Kiprah Perempuan di Arus Politik Indonesia" (Unpublished research report, Surabaya, 2005).

This competition recurred in subsequent parliamentary elections. In 1971, Golkar gained 54.9\%, while the Islamic parties, which later on merged into the PPP, obtained 39.4\%. At the time, the NU heartlands, such as Pasuruan, Banyuwangi, Bondowoso, Situbondo, Jember and Madura island and other regencies in the eastern areas, were not dominated by Golkar. Yet, the western areas adjoining Central Java, such as Ponorogo, Pacitan, Ngawi, Madiun and Bojonegoro, previously the stronghold of PKI and PNI, were entirely dominated by Golkar. ${ }^{70}$

${ }^{69}$ Ibid.

${ }^{70}$ Kompas, 6 February 2004. 
The next parliamentary election furthered the success story of Golkar. In 1977, Golkar raised its share of the vote to $59.2 \%$, whereas the PPP declined to just $35.9 \%$. Golkar won in Situbondo, Bondowoso, Jember, Sampang, and Sumenep, the regencies that had traditionally supported the Islamic parties. The power of the PPP was even poorer in the 1982 and 1987 elections; with NU's policy in 1984 of "going back to the 1926 khittab" which automatically meaning they withdrew from political life; thus the PPP's votes hit an all time low with just $21.4 \%$ in 1987. The PPP was beaten in almost all regencies, except Mojokerto, in which it remained undefeatable. In contrast, the Golkar reached $70.7 \%$, its highest ever proportion of the popular vote in East Java. ${ }^{71}$

Table 4: The Results of East Java Parliamentary Election (1971-1982)

\begin{tabular}{|c|c|c|c|c|}
\hline $\begin{array}{l}\text { Parliament } \\
\text { election }\end{array}$ & Parties & $\begin{array}{l}\text { Outcomes } \\
(\%)\end{array}$ & $\begin{array}{l}\text { Winning } \\
\text { concentration } \\
\text { (Parties basis) }\end{array}$ & Remark \\
\hline \multirow[t]{4}{*}{1971} & Golkar & $54 \%$ & $\begin{array}{l}\text { Ponorogo, Pacitan, } \\
\text { Ngawi, Madiun, } \\
\text { Bojonegoro }\end{array}$ & $\begin{array}{l}\text { Previously } \\
\text { stronghold } \\
\text { of PNI } \\
\text { and PKI }\end{array}$ \\
\hline & $\begin{array}{l}\text { NU and } \\
\text { Islamic } \\
\text { Parties }\end{array}$ & $39.3 \%$ & $\begin{array}{l}\text { Situbondo, } \\
\text { Probolinggo, } \\
\text { Pasuruan, Sidoarjo, } \\
\text { Surabaya, Gresik, } \\
\text { Pasuruan, } \\
\text { Banyuwangi and } \\
\text { Madura }\end{array}$ & \\
\hline & $\begin{array}{l}\text { Other } \\
\text { parties }\end{array}$ & $7.4 \%$ & & \\
\hline & Golkar & $59.2 \%$ & $\begin{array}{l}\text { Pasuruan, } \\
\text { Situbondo, } \\
\text { Bondowoso, Jember, } \\
\text { Sampang, Sumenep }\end{array}$ & $\begin{array}{l}\text { NU basis, } \\
\text { but won } \\
\text { by Golkar }\end{array}$ \\
\hline
\end{tabular}

1977

PPP $\quad 35.9 \% \quad$ Madura, Tapal Kuda $\quad$ Gained

71 Ibid. 


\begin{tabular}{lllll}
\hline $\begin{array}{l}\text { Parliament } \\
\text { election }\end{array}$ & Parties & $\begin{array}{l}\text { Outcomes } \\
\mathbf{( \% )}\end{array}$ & $\begin{array}{l}\text { Winning } \\
\text { concentration } \\
\text { (Parties basis) }\end{array}$ & Remark \\
\hline & & & $\begin{array}{l}\text { and north coastal } \\
\text { area. }\end{array}$ & $\begin{array}{l}\text { votes, but } \\
\text { defeated }\end{array}$ \\
& PDI & $5.4 \%$ & & \\
& Golkar & $69.8 \%$ & $\begin{array}{l}\text { Still dominant in } \\
\text { western areas and } \\
\text { won in nearly all } \\
\text { cities and regencies. } \\
\text { Madura and Tapal }\end{array}$ & \\
& & & Kuda areas & \\
& PPP & $25.60 \%$ & & \\
& & $4.8 \%$ & &
\end{tabular}

Source: Kompas, 8 June 1997 and 10 February 2004; Research and Development Division of East Java Kompas; www.situsjatim.com; Nurhasim, "Pengaruh dan Kekuatan Kiai," in Haris (ed.), Pemilu Langsung di Tengah Oligarki, p. 31; Asfar, Pemilu dan Prilaku Memilib; Ritonga et al., "Kiprah Perempuan."

In 1992, the PPP increased its share of the vote to $25.2 \%$, while Golkar though decreasing slightly, were still victorious with $58.8 \%$ of the total votes. Some municipalities and regencies that previously supported Golkar, were won back by the PPP. Such was the case particularly in municipalities and regencies in the eastern part of East Java. In 1997, the last election in the New Order era, the PPP continued its rise. In cities and regencies such as Bangkalan, Pamekasan, Jombang, Bondowoso and Surabaya City as well, where competition with Golkar was unavoidable. Pasuruan was the only area that was still dominated by Golkar. In general, the Golkar's votes reached 62.9\%, while PPP obtained 33.9\%..$^{72}$

Table 5: The Result of East Java Parliamentary Election (1987-1997)

\begin{tabular}{llll}
\hline $\begin{array}{l}\text { Parliament } \\
\text { election }\end{array}$ & Parties & $\begin{array}{l}\text { Outcomes } \\
\mathbf{( \% )}\end{array}$ & $\begin{array}{l}\text { Winning concentration } \\
\text { (Parties basis) }\end{array}$ \\
\hline 1987 & Golkar & $70 \%$ & $\begin{array}{l}\text { Dominated nearly all regencies and } \\
\text { cities }\end{array}$
\end{tabular}

72 Ibid. 


\begin{tabular}{|c|c|c|c|}
\hline $\begin{array}{l}\text { Parliament } \\
\text { election }\end{array}$ & Parties & $\begin{array}{l}\text { Outcomes } \\
(\%)\end{array}$ & $\begin{array}{l}\text { Winning concentration } \\
\text { (Parties basis) }\end{array}$ \\
\hline \multirow{5}{*}{1992} & PPP & $21.4 \%$ & $\begin{array}{l}\text { Madura and parts of Tapal Kuda } \\
\text { areas }\end{array}$ \\
\hline & PDI & $8.2 \%$ & \\
\hline & Golkar & $58.8 \%$ & $\begin{array}{l}\text { Fewer votes in Madura and Tapal } \\
\text { Kuda areas }\end{array}$ \\
\hline & PPP & $25.2 \%$ & $\begin{array}{l}\text { Significant votes in Pasuruan and } \\
\text { the eastern parts of East Java }\end{array}$ \\
\hline & PDI & $18.4 \%$ & \\
\hline \multirow[t]{3}{*}{1997} & Golkar & $62.9 \%$ & $\begin{array}{l}\text { Dominant in western areas, } \\
\text { Struggling in Tapal Kuda areas. }\end{array}$ \\
\hline & PPP & $33.9 \%$ & $\begin{array}{l}\text { Though defeated, gaining } \\
\text { significant votes in Surabaya, } \\
\text { Bangkalan, Pamekasan, Jombang, } \\
\text { and Bondowoso. }\end{array}$ \\
\hline & PDI & $4.2 \%$ & \\
\hline
\end{tabular}

Source: Kompas, 8 June 1997 and 10 February 2004; Research and Development Division of East Java Kompas; www.situsjatim.com; Nurhasim, "Pengaruh dan Kekuatan Kiai," in Haris (ed.), Pemilu Langsung di Tengah Oligarki, p. 31; Asfar, Pemilu dan Prilaku Memilib; Ritonga et al., "Kiprah Perempuan."

The 32 years of New Order political hegemony could not erase the political loyalty of East Java communities toward the identity and ideology of political parties. The result of the 1999 parliament election strengthened this assumption. Of 48 political parties competing in this province, the rivalry between parties that depended on the basis of Muslim mass and nationalist seemed more competitive. In general, East Java was the major base of the PKB in 1999.. The PKB gained $35.48 \%$, whereas the PDIP got $33.81 \%$. This relative share of the vote reminds us of the 1955 parliamentary election, in which political parties such as NU, PKI and PNI competed to obtain the influence/power in this area. In East Java, in $1955 \mathrm{NU}$ had obtained $34.14 \%$, the PKI $23.29 \%$, and the PNI 22.80\%. Meanwhile, Masyumi 
gained just $11.24 \% .73$ A predictably poor result was experienced by Golkar party. Where before, it had dominated six parliamentary elections during the New Order regime, Golkar now got only $12.7 \%$ in 1999.

The rivalry between the PKB and PDIP occurred up to regency and city level. Although, the PKB was dominant at provincial level, the PDIP dominated at regency and city levels. Around 23 regencies/cities in the western part of East Java were held by this party. The PKB merely dominated 13 regencies/cities and was concentrated in Tapal Kuda and Madura areas, excluding Pamekasan which was won by the PPP. This pattern was not very different from that of the 1955 parliament election. The cities/regencies in the western part of East Java was under domination of non-religious parties such as the PKI and PNI, while in the eastern areas, particularly Tapal Kuda and north coastal area the Islamic parties triumphed. The difference was that, while the regencies/cities of Malang, Jombang, and Sidoarjo in 1955 parliament election were dominated by NU, in the 1999 parliament election, PKB's share was less than the PDIP's. In contrast, Trenggalek, which in the past was of the base of the PNI, was won by the PKB rather than the PDIP.

The success story of PKB continued in 2004 with $31.3 \%$ of the votes while in contrast, the PDIP picked up only $24.3 \%$ of the votes. Apparently, traditional voters of PDIP voted for Golkar, which increased its votes to $15.3 \%$, and other nationalist parties like the Democrats. Geographically, the votes of PKB, PDIP or Golkar originated from their traditional regions.

Table 6: The Result of East Java Parliamentary Election in the Post New Order Era (1999-2004)

\begin{tabular}{llll}
\hline $\begin{array}{l}\text { Parliament } \\
\text { election }\end{array}$ & Parties & $\begin{array}{l}\text { Outcomes } \\
\mathbf{( \% )}\end{array}$ & $\begin{array}{l}\text { Winning } \\
\text { concentration } \\
\text { (Parties basis) }\end{array}$ \\
\hline 1999 & PKB & $35.5 \%$ & $\begin{array}{l}13 \text { regencies/cities: } \\
\text { Madura, Tapal Kuda } \\
\text { areas and Trenggalek }\end{array}$ \\
& & & $\begin{array}{l}23 \text { regencies/cities, } \\
\text { particularly in }\end{array}$ \\
& PDIP & $35.3 \%$ &
\end{tabular}

${ }^{73}$ Nurhasim, "Pengaruh dan Kekuatan Kiai," in Haris (ed.), Pemilu Langsung di Tengah Oligarki, p. 31. 


\begin{tabular}{lllll}
\hline $\begin{array}{l}\text { Parliament } \\
\text { election }\end{array}$ & Parties & $\begin{array}{l}\text { Outcomes } \\
\mathbf{( \% )}\end{array}$ & $\begin{array}{l}\text { Winning } \\
\text { concentration } \\
\text { (Parties basis) }\end{array}$ & Remark \\
\hline Golkar & $12.7 \%$ & $\begin{array}{l}\text { western and southern } \\
\text { regencies. }\end{array}$ & \\
& PPP & $5.2 \%$ & Votes slightly & $\begin{array}{l}\text { PDIP's } \\
\text { rival party } \\
\text { in }\end{array}$ \\
& PKB & $31.3 \%$ & $\begin{array}{l}\text { Surabaya } \\
\text { decreased }\end{array}$ & $\begin{array}{l}\text { Vote } \\
\text { migration } \\
\text { to PD }\end{array}$ \\
& PDIP & $24.3 \%$ & $\begin{array}{l}\text { Votes significantly } \\
\text { decreased }\end{array}$ & \\
\hline
\end{tabular}

Source: Kompas, 8 June 1997 and 10 February 2004; Research and Development Division of East Java Kompas; www.situsjatim.com; Nurhasim, "Pengaruh dan Kekuatan Kiai," in Haris (ed.), Pemilu Langsung di Tengah Oligarki, p. 31; Asfar, Pemilu dan Prilaku Memilih; Ritonga et al., "Kiprah Perempuan."

Looked at from a geo-political point of view, the general tendency of the voters' attitude in the parliamentary elections from 1955 to 2004 did not schange ignificantly. From 1955 onward the Mataraman area was dominated by the PKI and PNI, and in the 1971 parliamentary election was dominated by Golkar. Meanwhile, in post-New Order parliamentary elections, Golkar's position was rivaled by the PDIP. In this area, the votes of the PKB and/or NU-based political parties had never been significant. In contrast, however, they dominated on the island of Madura and Pendalungan. The performance of NU in the 1955 election was fairly strong, and such was the case in the 1999 and 2004 parliamentary elections, in which the PKB won in these areas.

In Arek and north coastal areas, nationalist and religious parties went neck and neck with no dominant political party. For instance, in the 1955 parliamentary election, in Surabaya and its surroundings, the 
NU and nationalist parties' votes ran very close. This trend wasrepeated in the 1999 and 2004 parliamentary elections, which the PDIP won in 1999 and the PKB won in 2004.

This pattern shows that geo-cultural and geo-political factors obviously had an impact on the community's political preferences. Later, this helps us to understand the participation of the NU elites in those five areas.

Table 7: Typology and Political Preference of the NU Elites in East Java

\begin{tabular}{|c|c|c|c|c|c|c|}
\hline \multirow[b]{2}{*}{ Areas } & \multirow{2}{*}{$\begin{array}{l}\text { Ethnics/ } \\
\text { language }\end{array}$} & \multirow{2}{*}{$\begin{array}{l}\text { Historical } \\
\text { relationship }\end{array}$} & \multirow{2}{*}{$\begin{array}{l}\text { Religion- } \\
\text { Politics } \\
\text { relationship }\end{array}$} & \multicolumn{3}{|c|}{ Political Tendency } \\
\hline & & & & $\begin{array}{l}\text { Old } \\
\text { Order }\end{array}$ & $\begin{array}{l}\text { New } \\
\text { Order }\end{array}$ & $\begin{array}{l}\text { Post } \\
\text { New } \\
\text { Order }\end{array}$ \\
\hline $\begin{array}{l}\text { Mataraman } \\
\text { (Madiun, } \\
\text { Magetan, } \\
\text { Nganjuk, } \\
\text { Kediri) }\end{array}$ & $\begin{array}{l}\text { Javanese/ } \\
\text { Central Java } \\
\text { (Keraton) }\end{array}$ & $\begin{array}{l}\text { Under } \\
\text { authority of } \\
\text { syncretic } \\
\text { Islamic } \\
\text { Mataram } \\
\text { Kingdom }\end{array}$ & $\begin{array}{l}\text { Rational, } \\
\text { prefer } \\
\text { substance to } \\
\text { symbol, } \\
\text { obedient to } \\
\text { king/state } \\
\text { leader, tend } \\
\text { to apply } \\
\text { politics } \\
\text { personally }\end{array}$ & $\begin{array}{l}\text { PNI and } \\
\text { PKI }\end{array}$ & $\begin{array}{l}\text { Golkar } \\
\text { and } \\
\text { PDI }\end{array}$ & $\begin{array}{l}\text { PDIP } \\
\text { and } \\
\text { Golkar }\end{array}$ \\
\hline $\begin{array}{l}\text { Pesisiran/ } \\
\text { North coast } \\
\text { (The northern } \\
\text { area Gresik, } \\
\text { Lamongan } \\
\text { and Tuban) }\end{array}$ & $\begin{array}{l}\text { Javanese/ } \\
\text { Eastern } \\
\text { Java (Arek } \\
\text { language) }\end{array}$ & $\begin{array}{l}\text { Orthodox } \\
\text { Islamic area }\end{array}$ & $\begin{array}{l}\text { Rational- } \\
\text { pragmatics } \\
\text { Substance } \\
\text { and symbol } \\
\text { walk } \\
\text { simultan- } \\
\text { eously } \\
\text { Kiai- } \\
\text { santri/comm- } \\
\text { unity } \\
\text { relationship } \\
\text { is more } \\
\text { rational. }\end{array}$ & $\begin{array}{l}\text { NU and } \\
\text { Masyumi }\end{array}$ & $\begin{array}{l}\text { PPP } \\
\text { and } \\
\text { Golkar }\end{array}$ & $\begin{array}{l}\text { PKB, } \\
\text { Golkar } \\
\text { and } \\
\text { PAN }\end{array}$ \\
\hline $\begin{array}{l}\text { Madura } \\
\text { island } \\
\text { (Madura } \\
\text { island) }\end{array}$ & $\begin{array}{l}\text { Madurese/ } \\
\text { Madura/- } \\
\text { East } \\
\text { Madura } \\
\text { (gentle), } \\
\text { West } \\
\text { Madura }\end{array}$ & $\begin{array}{l}\text { Traditional } \\
\text { Islam area } \\
\text { (Pesantren) }\end{array}$ & $\begin{array}{l}\text { Traditional, } \\
\text { charisma, } \\
\text { Rigidly } \\
\text { maintain } \\
\text { religious } \\
\text { tradition } \\
\text { symbol, }\end{array}$ & $\mathrm{NU}$ & $\begin{array}{l}\text { PPP, } \\
\text { some } \\
\text { are } \\
\text { Golkar }\end{array}$ & $\begin{array}{l}\text { Majority } \\
\text { PKB }\end{array}$ \\
\hline
\end{tabular}




\begin{tabular}{|c|c|c|c|c|c|c|}
\hline \multirow[b]{2}{*}{ Areas } & \multirow{2}{*}{$\begin{array}{l}\text { Ethnics/ } \\
\text { language }\end{array}$} & \multirow{2}{*}{$\begin{array}{l}\text { Historical } \\
\text { relationship }\end{array}$} & \multirow{2}{*}{$\begin{array}{l}\text { Religion- } \\
\text { Politics } \\
\text { relationship }\end{array}$} & \multicolumn{3}{|c|}{ Political Tendency } \\
\hline & & & & $\begin{array}{l}\text { Old } \\
\text { Order }\end{array}$ & $\begin{array}{l}\text { New } \\
\text { Order }\end{array}$ & $\begin{array}{l}\text { Post } \\
\text { New } \\
\text { Order }\end{array}$ \\
\hline & (rough) & & $\begin{array}{l}\text { Fanaticism to } \\
\text { Kiai }\end{array}$ & & & \\
\hline $\begin{array}{l}\text { Pendalungan } \\
\text { (Jember, } \\
\text { Banyuwangi } \\
\text { Bondowoso, } \\
\text { Situbondo, } \\
\text { Lumajang, } \\
\text { Pasuruan, } \\
\text { Probolingo) }\end{array}$ & $\begin{array}{l}\text { Madurese/ } \\
\text { Madura- } \\
\text { Java } \\
\text { (mixed) }\end{array}$ & $\begin{array}{l}\text { The } \\
\text { migrants of } \\
\text { Madura } \\
\text { island in } 19^{\text {th }} \\
\text { and the } \\
\text { beginning of } \\
20^{\text {th }} \text { century }\end{array}$ & $\begin{array}{l}\text { Traditional, } \\
\text { charisma but } \\
\text { pragmatics, } \\
\text { rigidly } \\
\text { maintain } \\
\text { religious } \\
\text { tradition } \\
\text { symbol, } \\
\text { Fanaticism to } \\
\text { Kiai }\end{array}$ & $\mathrm{NU}$ & $\begin{array}{l}\text { PPP } \\
\text { some } \\
\text { are } \\
\text { Golkar }\end{array}$ & $\begin{array}{l}\text { Majority } \\
\text { PKB }\end{array}$ \\
\hline $\begin{array}{l}\text { Arek } \\
\text { (Surabaya, } \\
\text { Sidoarjo, } \\
\text { Malang, } \\
\text { Jombang) }\end{array}$ & $\begin{array}{l}\text { Javanese/- } \\
\text { use Arek } \\
\text { Javanese } \\
\text { language, } \\
\text { some use } \\
\text { Madurese }\end{array}$ & $\begin{array}{l}\text { Most are } \\
\text { migrants } \\
\text { from various } \\
\text { areas in East } \\
\text { Java }\end{array}$ & $\begin{array}{l}\text { Rational } \\
\text { pragmatics } \\
\text { (due to the } \\
\text { influence of } \\
\text { metropolitan } \\
\text { popular } \\
\text { culture) } \\
\text { Egalitarian, } \\
\text { tolerant and } \\
\text { rational } \\
\text { cosmo- } \\
\text { politan) }\end{array}$ & $\begin{array}{l}\text { PNI, } \\
\text { PKI, } \\
\text { NU and } \\
\text { Masyumi }\end{array}$ & $\begin{array}{l}\text { Golkar, } \\
\text { PPP } \\
\text { and } \\
\text { PDI }\end{array}$ & $\begin{array}{l}\text { PKB } \\
\text { and } \\
\text { PDIP } \\
\text { are arch } \\
\text { rivals in } \\
\text { these } \\
\text { area }\end{array}$ \\
\hline
\end{tabular}

We should draw some distinctions between the political participation pattern during and after the New Order era. In the New Order era, the community's political participation tended to be 'mobilized' participation, and did not act completely from an awareness of their political choice. Their participation in political campaigns and in polling stations tended to be mainly due to pressures from the New Order regime. They were forced to obey the regime since they were afraid to be labeled as "Anti Development", "Right Extremists (Muslim Fundamentalists)" or "Left Extremists (Communists)". This stigma was quite effective in mobilizing the society to give political legitimacy to New Order regime. In contrast, in the "Reformation" era, political participation was more autonomous because the authoritarian New Order regime, which had used all 
means to conduct cooptation and penetration into all lines of life, had been terminated and transformed into a more substantive democracy.

In such a free political atmosphere, the motivation behind the political actions of the NU elites washighly varied. Among the crucial points has been the consideration behind their engagement to a certain political party. This case can be examined using Schultz's theory ${ }^{75}$ of "because motive" (motive that becomes the basis of political involvement) and "in order to motive". Based on this theory, the reason for the NU elites' political involvement is strictly religious. According to them, their involvement in politics is a religious obligation of each Muslim as stipulated in the Qur'aæ. Due to this instruction, joining politics is considered as part of devotion to God. God will grant reward in the Hereafter to those performing this instruction (the 'in order to' motive). In addition, Berger added a pragmatic motive, according to which a person conducts an action based on self-interest. ${ }^{76}$ In this context, the interest of kiais with their political involvement enables them to access power through their patronage over santris, alumni or links.

The political motivation of kiai is not permanent, because it can change due to pressure and continuous political conflict. In this context, the NU elites" involvement in politics is "symbolic" since they have struggled and improved the party, but there would be a possibility of withdrawal from politics (mufaragah) as shown by the resignation of some NU elites from the PKB and foundation of another party called PKNU. In this context, Blumer states that every human being has the wisdom to modify and changee. This happens because of their ability to interact with themselves, which enables them to examine a number of opportunities, assess their relative advantages and disadvantages and later on select one of the various opportunities. ${ }^{77}$

${ }^{75}$ Ian Craib, Teori-Teori Sosial Modern: Dari Parson Hingga Habermas (Jakarta: Rajawali Press, 1992), p. 126.

${ }^{76}$ Peter L. Berger, RJ. Neuhaus, "To empower people; the Role of Mediating Structure in Public Policy," in DC. Korten and R. Klauss (eds), People Centered Development (Connecticut: Kumarian, 1984), pp. 253-4.

${ }^{77}$ Blumer, Symbolic Interaction, p. 78. 


\section{The Politics of Abl al-Sunnab wa al-Jama $a b$; Symbolics and Pragmatics}

Besides the hybridization and amalgamation of culture that form the character of the political participation of the NU elites in East Java, fiqh (Islamic jurisprudence) also constitutes a distinctive feature of the NU elites' politics. As NU is a religious social organization, thus, it is only natural that religious values should function not only as basic rules within their religious rituals, but also should also be implanted into their wider life.

Religious values of Aswaja give the NU elites a flexible space to be further involved in a space that is social-politically not their discipline. The values developed by NU are flexible, universal and inclusive. Although there is an assumption that Aswaja political values are considered as legitimizing action for the NU social-political journey, the values indeed are substantially anchored in the Qur'a and Sunnah, the normative sources of Aswaja values.

Meanwhile, the most important aspect in Aswaja religious view is the fiqh. Fiqh discourse is more dominant than aqianh (Islamic theology), akblap(Islamic ethic) and tas downf (Sufism). Fiqh is widely used by the NU elites as a basic argument and response to socialpolitical issues that appear both within and outside NU. For instance, the principle of "conserving good values of the past and adopting

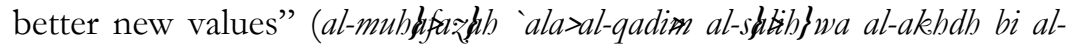
jadi al-aslah) $\}$ is always used by the NU elites in several important decisions, though legally it contradicts organization rules. By this norm, any conflicts between religion and politics can be overcome through reconciliation and therefore conflicts are avoided. One example of this is the involvement of Kiais listed as NU structural officials as well as being active in a political party. This double identity is basically forbidden in NU. Such conflicts of interest can be overcome through religious explanation and argumentation. The NU kiai involved in founding the PKB can remain active in $\mathrm{NU}$ as well as the PKB because of this logical reasoning. There was also the case of NU kiais who became officers, founders or active participants of PKB, then resigned and founded another party, the PKNU. All of these conflicting interests religiously can be accepted using this logical reasoning. This religious basis is also frequently used by the NU elites when they are considered of having broken the principle of "going back to the 1926 khittah", which strictly limits NU activities in social 
and religious programs. The consideration of NU benefit and service for national interest is often used as a reason by those who are both partyofficeholders and part of the NU structure.

Another jurisprudential maxim that is frequently used says that "if there are two conflicting hazards, then the least hazardous is

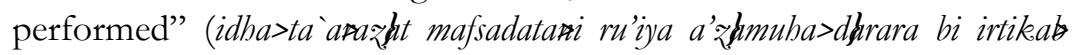
akhaffibima) $>$ This maxim is basically used in risk management. The political choices of the NU elites in anticipating social-politics consequences are made according to the measurement of the effects that could possibly result from those actions. Ali Haidar's claims, there is "nothing absolute" in the political tradition of the NU elites. ${ }^{78} \mathrm{By}$ this maxim, the move of the NU elites from the PKB to the PKNU or PPP is based on a consideration that the PKB is considered to have deviated from the principle of Aswaja and to have given no protection to Islam by appointing officers and legislative members of the PKB with non-Muslim. The religious motivation of PKNU figures in founding the party was to save the political aspirations of the group' or Jama'ah NU. According to some NU elites who resigned from the $\mathrm{PKB}$, on the grounds that non-Muslims and non-NU figures had been admitted to the PKB, it means that the PKB was in a hazardous condition and there should be a political mechanism to represent the political aspirations of NU community.

Another maxim that is frequently used is "avoiding hazards is more important than generating benefits" (dar' al-mafas muqaddam 'ala jalb al-mas f This maxim is used by the NU elites when they find themselves in a dilemma. Thus, they will take a decision that is able to reduce risks to a minimum rather than keeping pursuing benefits. In this context, the involvement of the NU elites in a variety of political parties, their resignation from the $\mathrm{PKB}$, and the founding of the PKNU is a part of minimizing the hazard after the failure of the PKB to implement the mandate of NU.

Suggestions for avoiding hazards is frequently related to the two broader principles of maslahth and amr bi al-ma'rufara naby an al-munkar. Maslahth (lit. "welfare" or "benefit") which are concepts in Islamic legal theory proposing that the ultimate goal of Islamic law is community interest or prosperity. As the contrary of maslahb hth is mafsadah, preventing mafsadat is maslahbhb. Interpretation and

${ }^{78}$ Haidar, Nahdlatul Ulama dan Islam di Indonesia, p. 322. 
implementation of maslahth by the NU elites is based on the decision making by measuring the advantages and disadvantages of the action to be taken. The way that gives most benefits or avoids most hazards is the most appropriate one.

Meanwhile, amr bi al-ma 'rup wa naby 'an al-munkar suggests encouraging good deeds and preventing cruelties. This concept is not a figh concept but a command taken from the Qur'ap, that is, what is explicitly stated in the Qur'a (3:104). Executing amr bi al-ma 'rußtwa naby an al-munkar is an obligation for every Muslim. According to Achmad Siddiq, besides personal obligation to give advice to government, he argues that NU can truly execute amr bi al-ma'ruplva naby an al-munkar through political participation within available political institutions. ${ }^{79}$

Based on his observation of NU's political experiences, Fealy proposes three principles, namely wisdom, flexibility and moderatism in politics that emanate from Aswaja teaching. ${ }^{80}$ The term wisdom is used within the definition of taking conducive action to gain benefits or to avoid the loss. Flexibility means NU always tries to adjust/adapt to the situation and never proposes an absolute or unconditional attitude. Furthermore, moderation may be defined as a wish to avoid an extreme position and greater care in acting and stating an opinion. In NU political discourse, these ideas are clearly held. Moderate manners, particularly the tendency to select common/general ways, known as the "middle way approach", is an Islamic value as well as a Javanese philosophy.

In the political history of the NU, since the Old Order up to the Reformation era, there have been numerous political decisions by the $\mathrm{NU}$ elites considered ambiguous and ambivalent. Accordingly, negative perceptions frequently emerged due to the lack of knowledge about NU's religious basis. Masyumi, for instance, considered the actions of NU inconsistent, weak, and opportunistic. ${ }^{81}$ On the other side, the political moves of NU were unpredictable. In one issue, NU was forceful to the ruling government but in another issue they were moderate. For example, NU kept a distance from the government

\footnotetext{
${ }^{79}$ Achmad Shiddiq, Kbittah Nabdliyyah (Surabaya: LTNU dan Khalista, 2007), p. 66.

${ }^{80}$ Fealy, Ijtihad Politik Ulama, p. 69.

81 Ibid., p. 77.
} 
during the New Order era, especially after the period of "going back to the 1926 khittah". This attitude is called, by Nakamura, "radical traditionalism". 82 In detail, Nakamura asserts that the political attitude of NU actually is "accommodative", but critical and autonomous. ${ }^{83}$

Before Nakamura, Geertz ${ }^{84}$ addresses the attitude of kiai as cultural brokers, namely activities that relate to the broader sociopolitical role of kiai in the community as spiritual guide, holder and controller of information, and determiner of a variety of local policies, including political issues.

What has the pattern of the NU elites' participation been like since the New Order age? Really, there have been two models of participation: "symbolic-pragmatic" and "symbolic- non-pragmatic". Symbolically, the political participation of the NU elites is described with a participation model that only lies on symbol and cover. It does not touch upon the real participation, which is based on religious faith. Ulama >kiai, and pesantren are used as symbols in carrying out political participation, particularly in founding a political party, and becoming an officer or member of a party. 'Ulama $\rightarrow$ nd kiai are symbols that are extremely close to spiritual and religious realms, so the involvement of kiai in politics is interpreted as the involvement of religion, or even the involvement of God in politics. From the political perspective, the NU elites can be regarded as symbols of God and religion in politics.

Symbolic participation tends to be artificial, by placing "instant interest" rather than a truly political struggle as the basis of politics, . It also tends to be "tenuous", strongly sensitive to interest and even conflict. This tendency can be observed, for instance in the movement of the NU elites from one party to another because of differences in opinion or their aspirations not being accommodated. Likewise, they easily form new parties on behalf of ulama>kiai, pesantren and even regard themselves as the only party that fights for Aswaja.

On the other hand, pragmatic participation is based on wellcalculated politics, measuring benefit and loss and their socio-

\footnotetext{
82 Mitsuo Nakamura, "Tradisioanalisme Radikal, Catatan Muktamar Semarang 1979," in Fealy and Barton (eds), Tradisionalisme Radikal, pp. 72-75.

83 Similar assertion is also stated by Fealy, Ijtihad Politik Ulama', p. 66; Muhtadi, Komunikasi Politik. Nabdlatul Ulama, p. 145; and Feillard, NU vis a vis Negara, p. 76.

84 Clifford Geertz, "The Javanese kijaji: the Changing Role of a Cultural Broker," Comparative Studies in Society and History: an international quarterly, 2,2 (1960): pp. 228-59.
} 
economic impacts. Pragmatic participation tends not to employ normative reasoning as a political platform. Instead, it relies largely on the fulfillment of instrumental matters and material gain. This model of participation is often followed by the NU elites in Madura, Pendalungan and some parts of the Arek area. In contrast, nonpragmatic participation frequently occurs in the NU elites of Mataraman area and a part of pesisir (coastal) area. However, not all of the NU elites in Madura, Pendalungan and Arek are pragmatic, because some of them firmly embrace the traditional doctrines of ulama $\rightarrow$ nd NU, so that they maintain the Islamic values of religious personalities. Likewise, not all NU elites in Mataraman and pesisir (coastal) areas are non-pragmatic, because a variety of maneuvers are is also found that are frequently considered contradictory to the values of ulama $>$ and NU.

Since the Reformation era, the opportunity of founding political parties has been well-utilized by Indonesians. As a result, any forms of political attitudes have been more tenuous and not dominated by a single political power. In this context, the NU elites have been more predisposed to get involved in politics because of their autonomous status. The transformation of political participation to "symbolic pragmatic" can be interpreted from the openness of the NU elites toward a political dynamic which is not "black and white" any more, but rather has a variety of colors.

\section{Conclusion}

Looking at geo-political and geo-cultural reality, the tendencies of political participation of the NU elites in East Java were prevalently heterogeneous. The NU kiais are in a position which is close to politics. It is normal for NU followers to consider the double roles of NU kiais; they are religious leaders dealing with spiritual aspects as well as community leaders involving themselves in social and potentially political aspects of life. However, this consideration occurs only locally, and cannot be implemented in the context of NU kiais nationally. The locality of political role is related to their social interaction with the culture in each area. Locality makes a contribution to understanding and perceiving politics; for instance, the Mataraman NU elites that tend to maintain a relationship with formal religious issues and there is a tendency to separate religion from politics. In contrast, Madura, Pendalungan, Pesisiran (north coast), and Arek areas tend to combine religion and politics. 
In the island of Madura and the Pendalungan area, the closeness of religion and politics is obvious in the utilization of religious symbols in politics. For example, kiais who attend formal meetings always wear robes and turbans as arguably religious symbols. Likewise, kiais who are members of local parliament always wear religious attributes in formal ceremonies. Those cases rarely occur in Mataraman or Pesisir (coastal) areas, in which they have commenced to differ between religion and state formal agenda, except the wearing of the peci (hat) which has become a part of the national dress.

In addition to the expansion above, there is another general characteristic that differentiates the NU elites of East Java from other Islamic elites (especially modernist Muslims). That aspect concerns the employment of principles of Islamic jurisprudence and legal theory in politics. There are different characteristics between these two Islamic groups because of a difference in social background. The modernist group, in general is highly driven by efforts to change the social reality of Muslims with regard to their religious practices. This religious experience finally is also applied to the change of political attitude. In contrast, the traditionalist group tries to coordinate, maintain and develop the faith, the religious culture that generally already exists. This attitude, in turn, has an impact on their view of social and political life. The argument that is commonly used is "al-mublat ala al-qadimalsqua al-akbdh bi al-jadidal-asl?h'? Accordingly, the first group tries to develop an ideal situation, while the second reflects social reality.

The fiqh-oriented approach used by the NU elites in responding to political issues culminates in the implementation of figh principles. It then creates the accommodative and pragmatic tendency of the NU elites. Evolution of political behavior can be observed by looking at the intellectual tradition and decision making process developed by NU. Due to the fiqh-oriented political responses, political style of the NU elites is more flexible and accommodative which is proven to provide solutions to any political dilemma. [] 


\section{Bibliography}

\section{Books and Articles}

Akhudiat. Masuk Kampung Keluar Kampung; Surabaya Kilas Balik. Surabaya: Henk Publica, 2008.

Alfian. Hasil pemilihan Umum 1955 untuk DPR. Jakarta: Leknas LIPI, 1971.

Almond, Gabriel A and Sydney Verba. Budaya Politik: Tingkah Laku Politik dan Demokrasi di Lima Negara. Jakarta: Bumi Aksara, 1990.

Amir, Zainal Abidin. Peta Islam Politik Pasca Soeharto. Jakarta: LP3ES, 2003.

Asfar, Muhammad. Pemilu dan Prilaku Memilih 1995-2004. Surabaya: Pustaka Eureka and PusDeHAM, 2006.

Asmawi. PKB; Jendela Politik Gus Dur. Yogyakarta: Titian Ilahi Press, 1999.

Bandura, A. Sosial Learning Theory. New Jersey: Englewood-CliffsPretice Hall Inc, 1977.

Bdr, Tadjoel Rizal. Tamparisasi Tradisi Santri Pedesaan Jawa. Surabaya: Yayasan Kampusina, 2004.

Beatty, Andrew. The Varities of Javanese Religion. Princeton: Princeton University Press, 1999.

Berger, Peter L and R.J. Neuhaus. "To empower people;the role of mediating structure in public policy." in DC. Korten and R. Klauss (eds). People Centered Development. Connecticut: Kumarian, 1984.

--------. Distinction. Cambridge: Cambridge University Press, 1984.

Bourdieu, Pierre. Outline of a Theory of Practice. Cambridge: Cambridge University Press, 1977.

Clifford, Geertz. "The Javanese Kijaji: the Changing Role of a Cultural Broker." Comparative Studies in Society and History: an international quarterly, 2, 2 (1960): pp. 228-59.

Craib, Ian. Teori-Teori Sosial Modern: Dari Parson Hingga Habermas. Jakarta: Rajawali Press, 1992. 
Fealy Greg and Greg Barton. Tradisionalisme Radikal; Persinggungan Nabdlatul Ulama' dan Negara. translated by Ahmad Suaedy. Yogyakarta: LKiS, 1997.

Fealy, Greg. Ijtihad Politik Ulama; Sejarah NU 1952-1967. translat. by Farid Wajidi and MA Bakhtiar. Yogyakarta: LKiS, 2007.

Friedman, J. "Global System, Globalization and The Parameters of Modernities." in M. Featherstone et al. (eds). Global Modernities. London: Sage Publication, 1995.

Geertz, Clifford. Abangan, Santri dan Priyayi dalam Masyarakat Jawa. Jakarta: Pustaka Jaya, 1981.

Haidar, Ali. Nabdlatul Ulama dan Islam di Indonesia; Pendekatan Fikih dalam Politik. Jakarta: Gramedia Pustaka Utama, 1994.

Harker, Richard et al. (eds). Habitus X Modal + Ranah = Praktik. Yogyakarta: Jalasutra, 2008.

Hefner, Robert F. in Andree Feillard. NU Vis a Vis Negara. transl. by Lesmana. Yogyakarta: LkiS, 1999.

Hikam, Muhammad AS. Demokrasi dan Civil Society. Jakarta: LP3ES, 1996.

Horikoshi, Hiroko. Kiai dan Perubahan Sosial. transl. by Djohan Effendi and Muntaha Azhari. Jakarta: LP3ES, 1987.

Ida, Laode. Anatomi Konflik NU; NU, Elit, Islam, dan Negara. Jakarta:Penebar Swadaya, 1996.

Kuntowijoyo. Perubahan Sosial dalam Masyarakat Agraris Madura 18501940. Yogyakarta: Mata Bangsa, 2002.

Muchtar, Masyhudi, and Mohammad Subhan. Profil NU Jawa Timur. Surabaya: LTNU, 2007.

Muhtadi, Asep Saiful. Komunikasi Politik Nabdlatul Ulama'. Jakarta: LP3ES, 2004.

Mulder, Niels. Agama, Hidup Sehari-Hari dan Perubahan Budaya. Jakarta: Gramedia Pustaka Utama, 1999.

Mustopo, Muhammad Habib. Kebudayaan Islam di Jawa Timur. Yogyakarta: Penerbit Jendela, 2001. 
Nakamura, Mitsuo. "Tradisioanalisme Radikal, Catatan Muktamar Semarang 1979." in Greg Fealy, and Greg Barton (eds). Tradisionalisme Radikal, Persinggungan Nabdlatul Ulama-Negara. transl. by Ahmad Suaedy, et. al. Yogyakarta: LKiS, 1997.

Nurhasim, Moch. "Pengaruh dan Kekuatan Kiai dalam Rekrutmen Politik." in Syamsudin Haris (ed.). Pemilu Langsung di Tengah Oligarki Partai; Proses Nominasi dan Seleksi Calon Legislatif Pemin 2004. Jakarta: Gramedia Pustaka Utama, 2005.

Parry, Geraint. Political Elites. London: George Allin and Unwin Limited, 1969.

Pieterse, JN. "Globalization as Hybridization." in M. Fetherstone, et. al. (eds). Global Modernities. London: SAGE Publication, 1995.

Ritonga, Iskandar. et.al. "Kiprah Perempuan di Arus Politik Indonesia." Unpublished Research Report, 2005.

Shiddiq, Achmad. Khittah Nabdliyyah. Surabaya: LTNU and Khalista, 2007.

Sutarto, Ayu and Setya Yuwana Sudikan (eds), Pemetaan Kebudayaan Propinsi Jawa Timur;Sebuah Upaya Pencarian Nilai-nilai Positif . Jember: Kompyawisda, 2008.

Sutarto, Ayu and Setya Yuwana Sudikan (eds). Pemetaan Kebudayaan Propinsi Jawa Timur; Sebuah Upaya Pencarian Nilai-Nilai Positif . Jember: Biro Mental Propinsi dan Kompyawisda Jatim, 2008.

Syam, Nur. Islam Pesisir. Yogyakarta: LKiS, 2005.

Syamsudin, Nazarudin. "Aspek-aspek Budaya Politik Indonesia." in Alfian and Nazarudin Syamsuddin (eds). Profil Budaya Politik Indonesia. Jakarta: Gramedia, 1991.

Thomson, M., A. Wildavsky R Ellis. Cultural Theory. San Fancisco: Westview, 1990.

Van Bruinessen, Martin. NU Tradisi, Relasi-Relasi Kuasa dan Pencarian Wacana Baru. transl. by Farid Wajidi. Yogyakarta: LKiS, 1994.

Woodward, Mark R. Islam Jawa Kesalehan Normatif Versus Kebatinan. translated by Hairus Salim HS. Yogyakarta: LKiS, 2006. 
Abdul Chalik

Yuswadi, Hary. "Budaya Pendalungan; Multikulturalitas dan Hibridasi Budaya Antaretnik." in Ayu Sutarto and Setya Yuwana Sudikan (eds). Pemetaan Kebudayaan Propinsi Jawa Timur; Sebuah Upaya Pencarian Nilai-Nilai Positif. Jember: Biro Mental Propinsi dan Kompyawisda Jatim, 2008.

Zuhro, Siti, et al. Demokrasi Lokal; Perubahan dan Kesinambungan NilaiNilai Budaya Politik Lokal di Jawa Timur, Sumatera Barat, Sulawesi Selatan dan Bali. Yogyakarta: Penerbit Ombak, 2009.

\section{Electronic Sources}

http://www.situsjatim.com

http://www.depdagri.go.id.

http://www.jatimprov.go.id.

\section{Newspapers}

Kompas, 8 July 1971; 8 June 1997; 6 February 2004; 10 February 2004.

\section{Interviews}

Akhudiat, Interview, 10 November 2008.

Syamsul Gentong, Interview, 23 November 2007. 